\title{
KEYNOTE ADDRESS SOUTHEAST ASIA: IMPERIAL THEMES
}

\author{
Wang Gungwu * \\ East Asia Institute, National University of Singapore \\ email: eaiwgw@nus.edu.sg
}

Published online: 15 July 2017

To cite this article: Gungwu, W. 2017. Keynote address Southeast Asia: Imperial themes. International Journal of Asia Pacific Studies 13 (2): 179-192, https://doi. org/10.21315/ijaps2017.13.2.9

To link to this article: https://doi.org/10.21315/ijaps2017.13.2.9

A celebratory conference of this kind should allow the keynote lecture to be somewhat more personal than normal. It is with that in mind that I have linked the theme, 'Southeast Asia: Past, Present and Future', to the person whose birthday we are celebrating. I do not know if I can do that successfully but will try by pursuing some of Nick's [Nicholas Tarling] and my own life and professional experiences with imperial themes in Southeast Asian history. Why 'imperial themes'? Would not that be too much of a bias towards the past? It would seem to ignore the conference theme to include both the present and the future. Of course, I have an historian's weakness for what is past; in this case, even 'privileging' a past paradigm that Southeast Asians today might prefer to forget. My excuse is that the party is for Nick, who is even more the historian than I am, and this is a rare opportunity for me to connect with him in the Southeast Asian context. But I shall not only talk about the past. I also hope to show that there are imperial themes in different contexts and different kinds of empires. Many of us wish to see the end of empires forever, and indeed some kinds of empires may have come to an end. But imperial themes are pervasive and resilient and may be more present than we think, and more relevant for the future than we would want. I recall suggesting a few months ago, when commemorating the end of the Second World War in Asia, that the kind of empire that the Japanese had tried to establish in Southeast Asia between 1941 and 1945 was gone and never to return. My audience thought that was wishful thinking and pointed out other imperial possibilities that might be subtler but 
no less imperial. I agree, though I still think that the old-style territorial empire that the Japanese tried to create will not be repeated. Indeed, the word empire is used today for many things: not only political entities but also business, financial, media and cultural empires and there are vague but cognate concepts in words like neocolonialism and neo-imperialism. I do not, however, wish to get into those areas in this lecture, but will concentrate on empires that project political power and influence.

Nick is a son of the British Empire while my father was born just before the collapse of the Manchu Qing Empire, both once powerful albeit in quite contrasting ways. However, I grew up in Malaya as a subject of Britain's global outreach, so there are some differences and similarities in Nick's and my perspectives. Thus, in approaching the topic of imperial themes, I shall begin with some reflections drawn from our two life experiences of empire from the centre and from the edges. After that, I shall explore three sets of changes and talk about, viz. empires becoming colonies, empires becoming nations, and finally, nations becoming empires. I shall then end with some reflections on future imperial themes.

Let me begin with the two of us finding ourselves in Southeast Asia. Nick started as an historian when the modern British Empire was still actively transforming itself into a commonwealth of nations. Britain was in the midst of orchestrating the establishment of a new class of sovereign states that would be friendly to their former imperial master. Nick would have studied in school the formative years of that empire, and probably a fair amount about the classical Athenian, Persian and Roman empires. Along the way, he was likely to have compared British imperial progress with those of Britain's rivals. I do not know how much of a classical scholar he was in school. If he were one, the rhetoric of the Roman Empire at its height would have shaped the language and imagination of the budding historian. Also, I know how much Nick loves the theatre. If that love had come early, then I would expect him to have absorbed the imperial cadences in Shakespeare's powerful words (and the images they conjured), from plays that I had also read such as Henry $V$, Julius Caesar, and Anthony and Cleopatra. When I think of Nick having done all that before he first stepped into the British archives, I can see why he is such a dedicated historian. I even wondered had he been born earlier, whether he would been content to be an historian of empire, whether he would not have been an empire-builder himself. Why act on a stage when you might have been, if not a Stamford Raffles or James Brooke or Frank Swettenham, at least George Orwell or Leonard Woolf? Nick, in any case, came on the swelling scene in time. He studied with Victor Purcell at Cambridge, and Purcell would 
have provided him with a rich personal perspective of the British Empire in multi-communal Malaya / Malaysia, when the last generation of imperial officials staged one final dramatic effort at state building in Southeast Asia.

In comparison, my imperial experiences were somewhat miscellaneous. I was born in the Netherlands Empire in the East Indies and grew up in Perak when it was a British quasi-sovereign protectorate (as a schoolboy, I always wondered what was being protected, British imperial interests or a nominal Malay sovereignty). Then there was an interlude during which I encountered the Japanese empire. Perhaps it was not typical of all empires at war, but I learnt from those three and a half years how bad empires could really be if they tried, and also how short-lived some empires could be. When that ended in 1945, the British returned, not quite in a blaze of glory, but they showed us how adaptable and resilient they were by setting out to re-invent what they would have to leave behind. I was never sure that we were being 'de-colonized' it felt more like we were 'de-imperialized'. Hence I had a second dose, this time of a chastened imperial power divesting itself of the burden if not the memory of empire.

Thus my education was a mixed bag, and even the imperial themes of my youth were contradictory. The only constant was that I was directed by what I was taught and what I lived through to question the glories of empire and ultimately welcome the end of empires. For example, the only history I remember learning in school was that of the British Empire, taught out of a very dull textbook by a teacher who was dutiful but obviously bored. The only correctives for me came from two sources. One was the Chinese classics that my father taught me during the Japanese occupation that introduced me to some notions of an ancient empire in China. The other was from the stories I heard from my Malay friends in school about the Malacca Empire from which the state of Perak claims to have been descended. Thus I was not in any way prepared for the serious study of history and the thought of being an historian never occurred to me.

When I first met Nick, he was in the enviable position of having direct access to the rich archives that all historians dream of. He had just started then but, as we all know, he has over the past 50 years made excellent use of these archives in the most systematic way. This was a great time for the imperial historians of Western Europe. There was a closure. The story, after centuries of splendid as well as dubious beginnings, now had an ending. The five acts were all there, the bodies could now be counted and the historian was ready to step up to say his piece as the curtain came down. In this case, he was free 
to analyze pithily the great and foul deeds or to draw a moral lesson for our times.

My fate was different. My generation in British Malaya was being prepared to face a new beginning, a nation-state modeled on those in Europe but, unlike them, given universal suffrage from the start, with our multiple communities filled with great hopes and even greater anxieties. Malaya was to be an example of what Rupert Emerson called the process 'from empire to nation'. But before I confronted that process, I had gone to China to study in the National Central University at the capital of a dying regime, the Nationalist government of Chiang Kai-shek [Jiang Jieshi, 1887-1975]. I was witness to a recently failed empire that was also a failed state still struggling to build a nation. In order to avoid being caught in the civil war that the Chinese Communist Party was to win, I returned to Malaya. The new Federation was then in the midst of a communist insurgency that challenged the kind of state that the British wanted to set up. At its climax, this had led to the killing of the British High Commissioner, Sir Henry Gurney [1948-51]. Despite that, I was introduced to a hopeful experiment, to British ingenuity busily nation-building on the foundations of a colonial state. At the University of Malaya, then in Singapore, I was fortunate to study with two remarkable historians. One was the historian of British India, Eric Stokes, who probed the underpinnings of the ideas behind Victorian imperialism. The other was Cyril Northcote Parkinson, the naval historian, who traced the decisive factors in British trading power that led them to Singapore and the opening of the China market. However, my taste for British imperial history had been killed at school. So I chose a different tack. My stay in Nanjing had drawn me to a puzzling question, why did the Chinese empire not simply become a nation-state in the first half of the twentieth century? So I began to study that generation in China who helped to abolish the ancient empire and got it to re-name itself a republic. Not only did this empire fail to become a united nation, but the nascent republic was also dogged by civil wars and foreign invasions. As a result, only a small part of its records were preserved and what survived in its divided archives was not open. Furthermore with the communist victory in China in 1949 and the anticommunist war in Malaya, it became impossible for me to study modern China without being suspected of harbouring 'terrorist' sympathies. By this time, I was determined to be a student of history, so I chose to examine the nature of the ancient Chinese empire instead, with an eye on the relations of that empire with Southeast Asia. Thus Nick and I, coming from different directions and looking at different time-scales, came to meet in Southeast Asia. 


\section{EMPIRES BECOMING COLONIES}

Let me now turn to my first point about empires becoming colonies. Neither of us, however, did research on the native empires of the region. We studied empires that had strong state foundations elsewhere whose origins and trajectories of growth were quite different. Nick's world was global with many nation-state protagonists each capable of reaching out faster and further than before. By the end of the eighteenth century, the British East India Company had consolidated its trading empire beginnings and was on the verge of transforming itself into a national empire built on industrial capital. As for me, I looked at a continental Chinese empire that consistently turned landwards. Even though it never lost its trading links with Southeast Asian ports, the Confucian state did not encourage state-to-state relations. It chose instead to slot Southeast Asian polities loosely into a tributary system that was originally invented for China's own internal use and thus kept the relationship somewhat feudal between rulers. All the same, both Nick and I were aware that there were native imperial themes at work in the region and followed the work of our colleagues with great interest, notably historians like Georges Coedes and Oliver Wolters on the Hindu-Buddhist states, scholars who did so much to stretch our imaginations about the imperial functions that these states performed. It was not a coincidence that we both concentrated on maritime Southeast Asia. This was the easternmost part of the British Asia that Nick focused on. I, of course, was born and grew up in the middle of that Malay world.

You may have noticed that I have used the word empire for very different kinds of states and that I was careful not to use its twin, the word imperialism. In fact, the definitions of empire are many because there have been so many empires in history but many of them could not be said to have been imperialist. Historians and political scientists have argued endlessly about what is common to all of them. For example, what do the ancient empires of India, China and Persia have in common with the modern British, Dutch and Japanese empires of the nineteenth and twentieth centuries? I shall come to that later. What about those empires in pre-modern Southeast Asia? The word empire has been used readily in our history texts today for the Angkor (or Zhenla-Khmer) and the Siamese empires on the mainland and Sri Vijaya, Majapahit and Malacca empires in the archipelago. One might add Vietnam if only because it is a reminder how elastic the term empire can be. There were empires to which other states paid tribute while they in turn offered tribute to the larger Chinese empire. 
I must admit I knew little about the local imperial polities before I went to university. I should have known more about Malacca. It was the closest both in geography and in spirit to the state of Perak where I went to school, but most non-Malays of my generation knew less about that empire than about the Portuguese capture of its capital in 1511. It took me years to understand the significance of Malacca's links with the empire of Sri Vijaya and its relations with the imperial states of Java, Siam and Ming China, and even longer to realize that, as empires, all these were very different from one another. I need hardly say that the European and Japanese empires that I had personally lived under were not at all like any of those mentioned.

As we know, parts of these empires ended up as examples of European colonies. But what do words like empire and colony mean here, especially when they are juxtaposed? If what the Portuguese strung together in the sixteenth century across wide expanses of ocean was an empire, and similarly what the Dutch did the next century was another empire, what does it mean to say that Malacca was a Portuguese colony and Batavia a Dutch colony? In fact, the Malay and Javanese empires did not disappear. The names changed and their centres moved but the traditions, the claims, the aspirations, and even the core elites, could trace their roots back to the same imperial origins. In a tradition that emphasized a mobile core, one empire's centre could become another empire's periphery and be regarded as the latter empire's domain. When threatened or defeated, new imperial centres could be found, established and defended afresh. Thus the empires of the archipelago had their own characteristics. Wolters decided to give them a special name. Inspired by the stories of several Sri Vijayan capitals that were precursors of the later Malay capitals, both on the peninsula and widespread across the Java Sea, he turned away from conventional references to vassal and satellite polities, and drew analogies with the concept of the mandala polities of South Asia. His analyses were most enlightening, but nothing could detract from the fact that the overarching frame was imperial, even if uniquely so.

This is not the place to debate the semantics of empire. My focus is on imperial themes. For maritime Southeast Asia, the theme was that of imperial mobility made necessary by weak state structures. A system of portable institutions was feasible because they were built on maritime trade. Such institutions appeared soft and plastic but they were stuck onto lightly assembled and resilient frames. In that way, people, genealogy and economic performance were more important than location and longevity. The loss of a port-city was replaceable, and sacred sites could be re-consecrated elsewhere. Clearly this was not the norm when compared with the larger and more stable 
empires of the period, but its strategy of survival persisted through the early centuries of European expansion from the sixteenth to the eighteenth centuries.

The land-based empires on the mainland did not support this form of imperial agility. The Hindu-Buddhist Khmers and the Sailendras in Java did move their centres from time to time, but their monuments were more grandiose and permanent and had to be fiercely defended. Similarly, the Vietnamese came south and took the lands of the Cham rulers, and employed the highly structured model of the Chinese. They too settled for imperial grandeur. As for the empires that succeeded the Khmers and the Mons on the Menam and Irrawaddy valleys, the Siamese and later the Burmese did no less to fortify each new city as they expanded their respective realms. They were thus less vulnerable to the modern maritime powers that came from the West who, in any case, got enough of what they wanted from the Malay networks of the archipelago. The mainland empires were not challenged for over 200 years. Only a new kind of empire would want to try to breach their walls. This was eventually developed in Europe by the British and the French during the nineteenth century, the product of high industrial capitalism. And it needed their brand of overwhelming power to turn these native empires, with the exception of Siam, into what was to be called colonies, in these cases, really subjugated states.

\section{EMPIRES BECOMING NATIONS}

This takes me to the second idea of empires becoming nations. I lived through the years of global decolonization and observed the process of turning former parts of empires into new nation-states. Nick's work on Britain's efforts to de-colonize while seeking to retain residual influence as long as possible was exemplary in reinforcing the image of orderly imperial retreat. I was so impressed by British success compared to Dutch failures in Indonesia and the French disasters in Indochina that I took for granted that that was the ideal way for empires to disband. More than that, the British Empire withdrew to become the Commonwealth of Nations. Despite adopting the broader Commonwealth name, Britain remained but a nationstate. Thus empires not only spawned nation-states but could also return to being one again. I found this intriguing because it was clear that this did not apply to empires that had never been nation-states in the first place. I was thinking of the China that I was trying to study. Sun Yat-sen [Sun Zhong Shan, 1867-1925] and his Nationalist Party thought they could take off their imperial coats and raise the 
republican colours, and thus make China a new nation-state. What they did not expect was that the national empires that impinged on China's sovereignty at the time saw China as a dying empire that could be reduced to several nationstates. By their definitions, there was 'China Proper' and there were the others that all qualified to be nation-states by right. Certainly, unlike the maritime empires, adjacent territories on the edges of empire were more difficult to detach. Britain looking north from India and Russia looking south from Siberia challenged each other to do just that and the stalemate between them helped to save territories like Tibet and Xinjiang from being removed from China. And between French and British competing interests, most of the original province of Yunnan stayed within Chinese borders. In that context, the Russians did help establish the Mongolian republic and the Japanese colonization of Taiwan has left a separation that haunts China still. On the other hand, the rival ambitions of the Russians and the Japanese prevented China from losing the provinces of Manchuria permanently.

As it happened, it had not been possible for me to do research on modern China in Malaysia. So I looked at the Chinese empire in its trade with the Southeast Asian ports of the South China Sea. They led me to the origins of the tributary system devised for a tianxia, or 'All Under Heaven', that John King Fairbank called 'the Chinese world order'. This new term suggests that, by the criteria that defined empires in European history, China was not quite the kind of empire they were familiar with. All the same, as shorthand, everyone used the word empire for China until 1911. What is interesting is that, long after 1911, the shadow of empire still seems to follow China around. No matter that, officially, all countries recognize China as a large multi-nation state and accept its international borders, and it has been easy for regions like Southeast Asia to be pointed to as targets of a future 'China threat' because of its imperial past.

It is true that the Qin-Han Empire advanced into the Red River valleys of northern Vietnam over 2000 years ago and stayed over 1000 years. It is true that, for some 600 years, the kingdom of Dali and the tribal statelets of Guizhou and Yunnan were gradually incorporated into Ming and Qing imperial provinces. It is also true that vague terms like feudal and tributary relations, vassalage and suzerainty, left us unclear whether they might be used again in future relationships. I had gone on to study North China during the late Tang and Song dynasties, covering a period when the Chinese empire was weak and divided. This was when Chinese emperors paid tribute to other emperors stronger than themselves. My study led me to examine other manifestations of 
empire in Asia. For example, the Mongol conquest of China under the Yuan dynasty led to aggressive activity in Southeast Asia, including the invasion of Burma, Vietnam, Champa and Java (and Korea and Japan as well). The climax of these actions came after the Mongols were driven out when the Ming emperor Yongle [1402-24] sent the eunuch admiral Zheng He [Cheng Ho, 1371 / 1375-1433 / 1435] on naval expeditions to the Indian Ocean and the coast of East Africa. (I suggest that you do not trouble yourselves with the unfounded claims that his ships visited New Zealand!) I studied the reasons for Emperor Yongle's fleets to travel to and through Southeast Asia and it was clear that he had extended the tributary system across the oceans in an unprecedented way. The decision, however, was his and, after his death, there was no sustained interest in maritime affairs or in political relations. There remained some official trade with Southeast Asian kingdoms, but the only naval forces left were maintained to fight piracy on the Chinese coasts and, under the Manchu Qing rulers, to capture Taiwan from the Ming loyalists there.

This imperial theme touched the region lightly and surfaced from time to time, most notably when armed Chinese and Japanese trading consortia under Zheng Chenggong [Koxinga, 1624-62] and his father had threatened the empire during the Ming-Qing transition of the seventeenth century. After that, China passively accepted that several Southeast Asian ports were garrisoned by Europeans and was content to limit or deny these traders any rights in Chinese ports themselves. The lights of empire began to dim for China by the end of the eighteenth century although the mandarins were still unaware of the power shifts the British had made in the region. Yet it remained an empire where Manchu invaders ruled over the Han majority and the idea of nationhood, as we understand it, was not much more than a strong sense of multiple local Han ethnicities. Thus I came to understand how difficult it was for an empire to become a nation-state if it was never one in the first place. From that point of view, imperial Britain's experiments at nation building, however imperfect they have been, provided a far stronger base for nationhood than anything imperial China could have done for its own peoples. But, now that the Chinese are embarked on their nation building tasks, will they understand what it means to be a mere nation-state? Will they be content to be that or will they learn from Europe and Japan that nations could be aggrandized to become empires? 


\section{NATIONS BECOMING EMPIRES}

Let me now turn to how nations became empires and look at the changing imperial themes brought by the Europeans to Southeast Asia. The earlier empires were primarily trading ventures initiated by kings or merchants before the age of nation-states. This was certainly true of the Dutch and English East India companies that competed aggressively in the archipelago. Each went on to take imperial shape and evolved imperial characteristics over a couple of centuries. Before the Dutch and the English, the Portuguese and Spanish did have missions that could be traced to deeper medieval roots. The Portuguese proclaimed to have come to the East in search of 'Christians and gold', and this was also the understanding of the Spanish crown. This mission survived from the spirit of the Crusades, an outreach of the struggles over trade and the Holy Land. It gave the Spanish settlements in the Philippine islands a distinctive imperial theme that the Portuguese tried less successfully to match in their small toeholds off the coasts of India, China and the Malay Peninsula. The side commitment to find Christians, however, remained and served as an ideological sub-text common also to the European peopling of the Americas. It carried an imperial theme that was pre-national but was both universal and enduring, and elements of this mission to bring the truth to less fortunate natives have survived till the present day.

By the eighteenth century in Southeast Asia, the trading roles of the Dutch and the English had become dominant. Gold was acknowledged to have been more important than Christians, especially with the rise of the country traders bypassing the English East India Company. A century later, with the success of the industrial revolution in Britain, the shift was decisive and one could speak of capitalist empires in search of markets, primary resources and ultimately territorial control. This was certainly truer of Britain than of the Netherlands. The greater need to provide and support the factories of the former pushed the British to go further than any other trading empire in history. This is the story that Nick and his colleagues had to tell. Clearly, there were new imperial themes during the nineteenth century that transformed the nature of empire in Asia. The British led the way. They took on more onshore responsibilities in India and turned the tea and opium trade into casus belli, and they dominated the maritime routes through Southeast Asia and subordinated the Chinese empire to a different imperial framework.

Economic power was the key, but the shift from commercial ventures to industrial needs whether markets, mines or plantations, were not nearly as dramatic as what was the really new feature of the empires of the nineteenth 
century. Nick drew attention to this point in one of his earliest essays, written almost fifty years ago, 'The Relationship between British Policies and the Extent of Dutch Power in the Malay Peninsula, 1784-1871'. ${ }^{1}$ I read this when I was still freshly under of the influence of Parkinson's majestic two volumes, Trade in the Eastern Seas, 1793-1813 and War in the Eastern Seas, 1793-1815, about the rivalry between the two foundation nation-states of the modern world, post-Napoleonic France and Britain. Nick's thesis showed that the Dutch nation-state was thereafter adjunct to its larger neighbours and this determined the future of its empire in Southeast Asia. What really changed was that companies, merchants, wealth and profits were no longer the key determinants of power shifts. The consequences of British national victory over the French was the emergence of national empires, a model that spread the link between empires and national pride and glory to other rising nationstates in continental Europe and ultimately to the United States of America.

What are national empires? Aren't all empires national? Obviously there cannot be such phenomena before the creation of nation-states. For example, it would be totally anachronistic if not absurd to describe Sri Vijaya, Majapahit or Malacca as national empires; likewise with the Angkor- Khmer, the Siamese or the Burmese. The only exception may be the Vietnamese because their identity hinged on differentiating themselves from the 'Chinese'. It did not matter to them whether Han, Mongol or Manchu elites ruled the larger empire to their north. Vietnam survived as what D. G. E. Hall called a proto-national state. That, however, did not save them from becoming part of the French empire in Asia, and France was the classic national empire, something that Asia was only just beginning to encounter.

It is at this point that national imperialism was added to the original imperial themes. It not only had its source in industrial capitalism, as J. A. Hobson [1858-1940] and V. I. Lenin [1870-1924] were later to argue, but was strongly linked to the rising urge to national aggrandizement and ultimately to exaggerated claims to political, technological and even cultural and racial superiority. I emphasize the 'rising urge' because I do not suggest that this was the origin of national empires. Commercial competition was central long before national pride and glory became factors in empire building. It was only after the end of the eighteenth century that British national ardour to defeat and keep out the French, and then the German, the Russian and any other likely rivals, became a primary concern. And that was to engage Britain for the next 150 years. At first, Britain's Indian empire was the challenge, if not the only model, for other ambitious powers. But this developed into a British-led battle for greater share and control of the markets of China. Soon each European 
nation-state would join the race to capture as much as possible of that market before others arrived. In that context, Southeast Asia seemed to some to have become a sub-plot in the imperialist play.

However, Nick has written much on these developments to correct such a description. He unfailingly searched the archives to prove that the region was never a sub-plot but a key link connecting the new imperial themes of the nineteenth and the first half of the twentieth centuries. His series of studies took us step by step through all the ins and outs of the British Empire at its zenith and they have provided much of the evidence we need to show that Southeast Asia was a vital part of the globalizing chain of modern empires. In so doing, he has also enabled us to read the writings of Eric Hobsbawn, Linda Colley and, more recently, Ben Anderson, with specific reference to the model of British nation-formation and the changing roles that new projections of imperial power played in the politics of the Malay peninsula and archipelago. Nick has now followed that up with studies of later British efforts at state building and their belated efforts to decolonize the territories under their control or protection. The goal was to mould them into nations despite the harsh reality of having helped to draw new national borders with little historical validity.

Two of the imperial themes concerning nations becoming empires deserve attention. The rich documentation of national empire building is invaluable, showing how a maritime trading empire grew to become the world's greatest naval power and shaped the British imperial nation. That united and confident nation continued to grow almost unchallenged for at least half a century. It set high standards of national superiority, the idea that the nation-state was the most efficient instrument of imperial power. Some would argue that this also led to arrogance and complacency. Then came the challengers all impressed by Britain's success and by the efficacy of the nation-state model. Several of these sought to become national empires themselves, notably industrial Germany, the United States and Japan. Even the large and ponderous Russian empire expanded overland towards British spheres of control and influences only to be replaced by an even more threatening Soviet power. In short, national empires encouraged rivals who were intent on making their own nation-states stronger and greater.

The second theme could be framed as a question: will new aspiring nation-states have the capacity to be national empires in the post-Cold War world? The question has been asked since the European powers began to withdraw from their empires in Southeast Asia half a century ago. There was a rejuvenated nationalist China followed by a messianic communist China, there were international revolutionary movements within Southeast Asia that 
had attached themselves either to the Soviet Union or to the People's Republic of China. Although every nation-state rejected the idea of empire after the end of the Second World War, there were no guarantees that some imperial forms would not return or new imperial themes could not be invented. The most powerful nation-states after that war were the United States and the Russian core of the Soviet Union. Although in some eyes, one was benign and the other evil, how different were the two from behaving like national empires in the deadly rivalry that energized them?

What is at stake is the nature of the international system that was predicated on the universal acceptance of nation-states as primary political units hereafter. When countries vary so much in size and power, it is difficult to believe that the system can ensure equality among nations. The example of a Western Europe weary of war and empire could be a catalyst to warn against future glorification of old nation-state values, but much more influential is the dynamic engine of growth provided by the United States that has already transformed East and Southeast Asia and seems willing to do the same elsewhere. With the coming rise of China and India, there is more economic growth forthcoming. This brings me back to the contrasting experiences that Nick and I have been studying. On the one hand, there is the Anglo-American model sharing the outgoing European tradition of 'Christians and gold' that had opened up the American continent and swept up on the shores of Southeast Asia. On the other, there is the populous Chinese example of a former empire yet uncertain about the kind of nationstate it expects to become. The former now has gold enough to turn attention to a mission of values. The latter still has to guard against making the same mistakes that new rising nations had made only a few decades ago. My study of Chinese history suggest that the lesson has been learnt, that China's acceptance of international norms comes not only from national interest but is also influenced by the system of political and social values that had shaped its relations with Southeast Asia for more than 2000 years.

Southeast Asia's present is still based on how it adjusts to Asia's new confidence, how much to retain of its imperial experiences and how much it can organize its nation-states to deal with global markets and the national powers that could have imperial potential. It is unlikely now that its Asian neighbours will follow the nineteenth century European example of national aggression or the twentieth century revolutionary impulse to determine the regime changes of other nations. There has been enough history written about the horrendous disasters of the two centuries to alert the region's leaders to cooperate with one another. It is time to consolidate the regional groupings 
that could protect the region's long-term interests. The imperial themes that the region has been through have been varied. Their histories can be conjoined to help us outline some future scenarios. I believe Nick's birthday has provided us with an opportunity to pool the many fields represented here to reflect our present and help construct our future.

\section{NOTES}

1 Australian Journal of Politics and History (AJPH), 4, 2 (November 1958), pp. 179-92. 